\title{
Chudley-Lowry-Hoar syndrome
}

INSERM

\section{Source}

INSERM. (1999). Orphanet: an online rare disease and orphan drug data base. ChudleyLowry-Hoar syndrome. ORPHA:93971

Chudley-Lowry syndrome is an X-linked mental retardation (XLMR) syndrome belonging to the group of conditions characterised by the association of intellectual deficit with hypotonic facies (Mental retardation-hypotonic facies; see this term). 